Abstract\#: A-2021-RE10027

Tao Xingzhi Study Association of China \& Huzhou University

May 28-30, 2021, Huzhou, Zhejiang Province, China

\title{
The Application Research of Analogy in Science Teaching in Junior High School
}

\author{
Wei Yu \\ Affiliation: Yuhuan Chenyu Middle School, Taizhou 317604, Zhejiang, China \\ Address: Yuhuan Chenyu Middle School, Taizhou 317604, Zhejiang, China \\ Correspondence to: Wei Yu, E-mail: kmyz_yw@qq.com \\ DOI: https://doi.org/10.15354/sief.21.s1.ab053 \\ The authors declare no competing interest.
}

The importance of resolving the problem of reducing students' burden is to establish in the classroom. Through exploring the micro-research, the author found that the class must be delightful, enjoyable, and well-regulated so that students could be fond of learning, enjoy learning, and be good at learning. In teaching, appropriately using the analogy is one of the practical methods. The analogy can motive students to have learning interests, enlighten their thinking, and expand their horizons. Applying analogy appropriately can promote students to understand scientific concepts, principles, and regulations. In this way, students will improve their learning efficiency. It is significant to reduce students' burden and improve teaching quality. This paper elaborated the application of analogy in junior high school's Science teaching from four aspects: connotation, function, application principle, and development approach. From the micro-research of analogy, this paper aims to improve teaching efficiency, reduce students' load, and provide other educators with examples.

Keywords

Science in Junior High School, Analogy, Application Research

Science Insights Education Frontiers, 2021 September 13; Vol. 10, Suppl. 1, pp.23.

(c) 2021 Insights Publisher. All rights reserved.

(c) (i) Creative Commons Non Commercial CC BY-NC: This article is distributed under the terms of the Creative Commons Attribution-NonCommercial 4.0 License which permits non-commercial use, reproduction and distribution of the work without further permission provided the original work is attributed by the Insights Publisher. 